\title{
Jakob Ulfeldts fuldmagt vedrørende sine børn
}

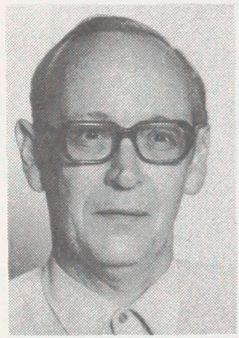

af forskningsbibliotekar

Harald Ils $\phi$ e

Da den franske gesandtskabssekretær Charles Ogier 1634 bes $\varnothing$ gte Danmark, noterede han, at de hof-og embedsmandskredse han kom i forbindelse med besad dannelse og kultur på højt europæisk niveau. Den danske hфjadel viste sig at være både sprogkyndig og rig på kundskaber, hvad han bl.a. kunne bevidne for Rosenkrantzernes og Ulfeldternes vedkommende. Blandt de første var der teologer, lige dygtige $i$ åndelige og verdslige videnskaber, og blandt de sidste fremhævede han de tre brødre Knud, Laurits og Corfits, som hver talte 6-7 sprog fortræffeligt og forstod endnu flere. En dansk adelsmand, som ikke havde studeret, mente Ogier, blev næppe anset for en sand adelsmand.

Det europæisk orienterede dannelsesstade, som imponerede ikke alene Ogier, men også andre besøgende i Danmark, var en følge af ikke sjældent langvarige studie- eller dannelsesrejser ude i Europa. Det var fra sidste halvdel af 1500-tallet og gennem hele 1600-tallet en rådende grundindstilling, at unge under en eller anden form for boglig uddannelse - adelige såvel som borgerlige så vidt muligt burde tilbringe nogle år ved udenlandske skoler, akademier eller universiteter, førend de tiltrådte stilling i hjemlandet. Så selvfølgelig forekom tanken, at den knap nok findes nærmere motiveret. Der var naturligvis ganske mange studenter, der ikke havde råd, men for at st $\phi$ tte de ubemidlede blev der stiftet rejselegater, ligesom velmenende adelsmænd og adelsfruer 
af egen lomme kunne finde på at finansiere en velanbefalet students udenlandsophold. Desuden havde en dygtig og hæderlig student chancen for at blive hyret som lærer og vejleder for yngre adelsjunkere eller velhavende borgers $\phi$ nner, som forældrene nфdigt slap ud i verden på egen hånd. En sådan såkaldt præceptor eller hovmester var rejseleder, ansvarlig for udf $\phi r e l s e n$ af det $\varnothing$ nskede læreprogram og bestyrede pengekassen. Til gengæld fulgte han gratis med og kunne ved siden af dyrke egne studier. Derudover fik han et mindre honorar og havde, om han ellers slap godt fra hvervet, gode udsigter til embedsbefordring ved hjemkomsten.

\section{NOGET OM LITTERATUR OG KILDER}

Udenlandsrejsen har som det vigtige socialhistoriske og kulturhistoriske fænomen, den er, i stigende grad været genstand for historikernes opmærksomhed. I 1981 var universitetsbes $\phi$ gene i udlandet $\mathrm{f} \phi \mathrm{r} 1660$ tema ved det 18. nordiske historikerm $\phi$ de, fra dansk side behandlet af Vello Helk, se Ur nordisk kulturhistoria. Universitetsbesöken $i$ utlandet före 1660, 1981 (= Studia historica Jyväkyläensia, 22,1), s. 27-65. Her har Vello Helk forelфbigt sammenfattet mange års systematiske unders $\varnothing$ gelser af danske udenlandsrejser 1536-1660, der nu snart vil resultere i et større bogværk. Interesserede kan videre henvises til fyldige (og illustrerede) forstudier sorn "Dänische Romreisen von der Reformation bis zum Absolutismus" i Analecta Romana Instituti Danici VI, 1971, s. 107-96, og stambogsstudierne i Fund og Forskning XXIXXIV, 1974-80, også samlet $i$ en særudgave med titlen Vello Helk: Stambøger $i$ Det kongelige Bibliotek før 1800, Kbh. 1980. Iøvrigt kan det danske rejsemønster med udbytte jævnf $\phi$ res med det tilsvarende svenske. Lars Niléhn har grundigt behandlet de svenske studierejser i Peregrinatio academica. Det svenska samhället och de utrikes studieresorna under 1600-tallet. Lund 1983 (= Bibliotheca historica Lundensis LIV).

Kilderne til udenlandsrejsernes historie er talrige, men spredte. Først og fremmest må det ydre studieforl $\phi b$ f $\phi$ lges gennem de europæiske universiteters, gymnasiers og akademiers matrikler. Fra tiden $f \phi r 1700$ er de fleste af dem efterhånden trykt og på grund af deres personalhistoriske referencekarakter næsten alle erhvervet til Det kongelige Bibliotek. De tyske læreanstalter 


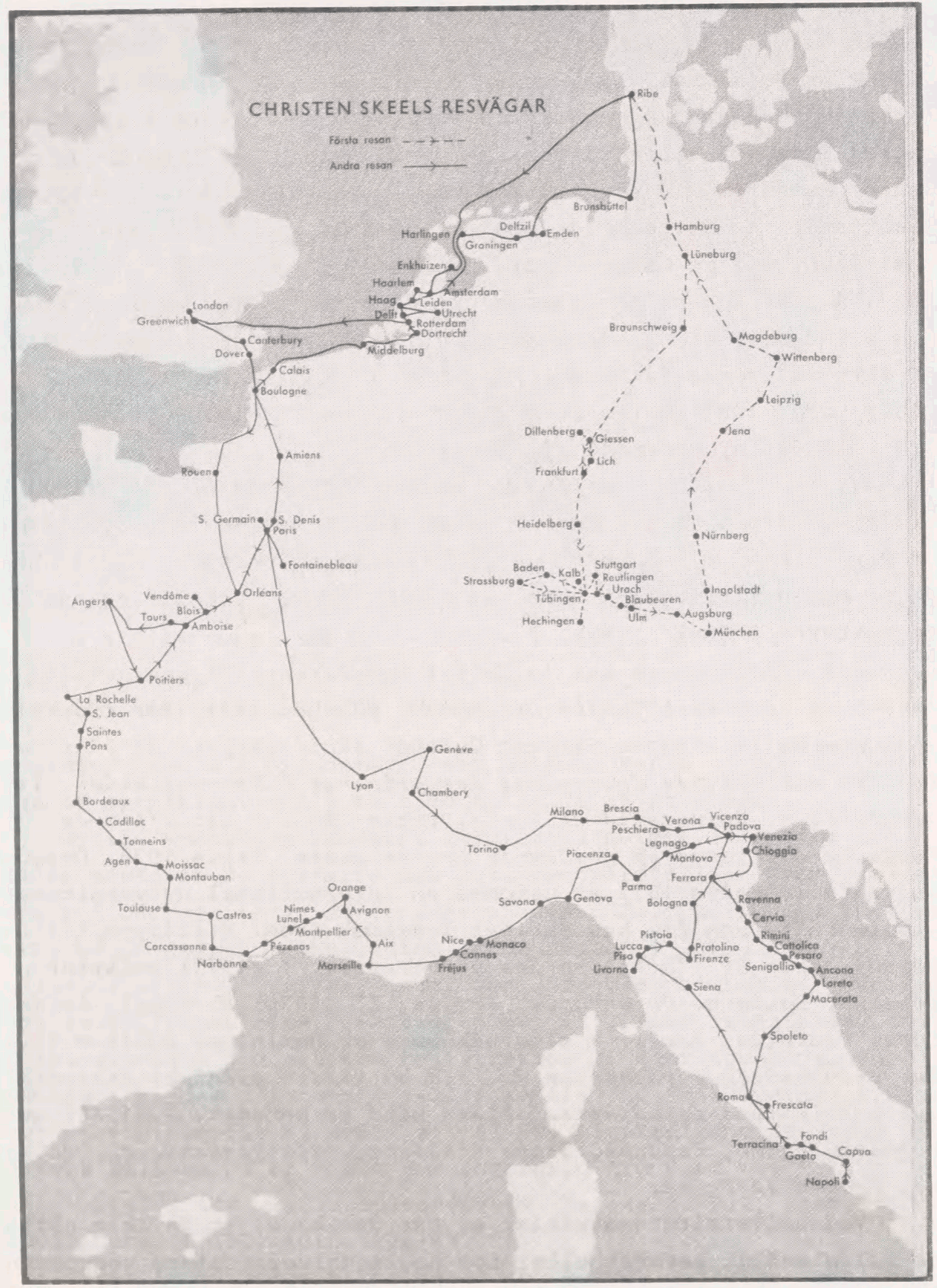

Christen Skeel (1603-59) var søn af lensmanden på Riberhus og gik først $i$ Ribe skole. 16 år gammel blev han sendt til Tyskland og opholdt sig 1619-22 på adelskollegiet $i$ Tübingen (rejsemute angivet ved stiplede linjer). Efter et bes $\phi g$ hjemme foretog han derpå 1623-27 den typiske store tur gennem Nederlandene og England til Frankrig og Italien (angivet ved sort streg med pil). Fra udgaven af hans rejsedagbog nceunt s. 42 . 
blev særlig hyppigt bes $\phi$ gt af nordiske studerende, og nyttig er derfor en oversigt over trykte matrikler $i$ de tysksprogede lande, Karlheinz Goldmann: Verzeichnis der Hochschulen. Neustadt 1967. De mange udenlandske matrikeludgaver er gennem årene fulgt op af uddrag i danske tidsskrifter, hvori de relevante oplysninger om danske studerende gengives, som regel med tilf $\varnothing j e d e$ personidentifikationer. En fortegnelse over disse uddrag til 1962 giver Albert Fabritius og Harald Hatt: Håndbog i slegtsforskning, 3. udg. 1963, s. 120-21; et supplement til 1972 er leveret af Hans Worsфe i Personalhistorisk Tidsskrift årg. 93, 1973, s. 78-79. Senere matrikeluddrag er meddelt af Vello Helk i samme tidsskrift $1980 \mathrm{ff}$ årg. 100 (Bourges), årg. 102 (Genève), årg. 105 (Siena) og årg. 106 (Köln, Montpellier, Lauingen).

Logisk bliver de udenlandske læreanstalters historie til en vis grad en del af den danske uddannelseshistorie, og sфger man nærmere viden om de bes $\varnothing$ gte universiteter og deres miljøer, kan en og anden bibliografi være til hjælp. Nyere tysk litteratur er registreret i Edwin Stark: Bibliographie zur Universitätsgeschichte. Verzeichnis der im Gebiet Bundesrepublik Deutschland 1945-1971 veröffentlichten Literatur. München 1974. For Frankrigs vedkommende foreligger Simonne Guenée: Bibliographie de l'histoire des universités françaises des origines à la révolution. I: Généralités. Université de Paris. Paris 1981. - II: D'Aix-enProvence à Valence et Academies protestantes. Paris 1978. Desuden begyndte i Genève 1973 at udkomme en international universitets bibliografi, som dog kun skrider langsomt frem: Bibliographie internationale de l'histoire des universités. I (1973) omfatter Espagne. Louvain. Copenhague. Prague, II (1976) Portugal. Leiden. Pécs. Franeker. Basel. - Lige udkommet er Dominique Julia m.fl.: Les Universités europeénnes du XVI ${ }^{e}$ au XVIIIe siècles: Historie des populations éstudiantes. Flere bind er bebudet. I (1986) behandler Bohème, Espagne, Etats italiens, pays germaniques, Pologne, Provinces-Unies.

Ved universitetsmatrikler er der den hage, at de ikke altid er fuldstændigt bevaret eller for nogle universiteters vedkommende slet ikke eksisterer. Vello Helk har i rigt mål dokumenteret, at stambøgerne med deres daterede navneindførsler så kan træde til og udfylde huller $i$ kortlægningen af rejserne. Hertil kommer at stambogsindf $\varnothing$ rsler kan bevidne studieophold $i$ byer, hvor universiteter enten ikke fandtes eller ikke blev frekventeret af ud- 


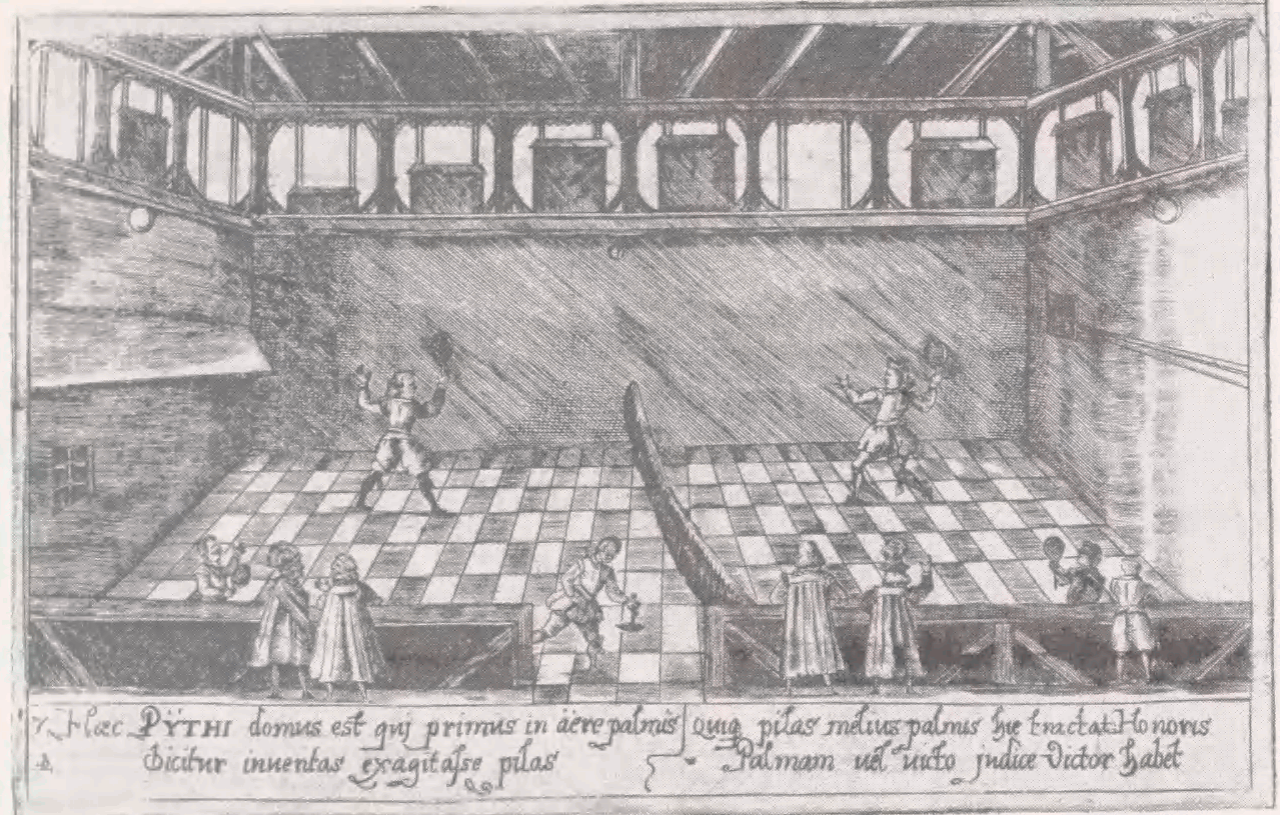

På adelskollegiet $i$ Tübingen kunne de unge adelsmcend - som også senere på Sor $\varnothing$ akademi - dyrke sportslige og ridderlige fcerdigheder. Kobberstik af boldsalen i J.C. Neyffer: Novi Collegii ... Tubingce... Delineatio. 1626.

lændinge. Ophold i hovedstæder som London, Paris og Rom bevidnes ikke af matrikler, men i talrige tilfælde af stamb $\varnothing$ ger.

Skulle stambogsmaterialet imidlertid svigte, udfyldes andre huller måske af de desværre kun betinget pålidelige levnedsskildringer i ligpredikener og sørgeprogrammer. Internationalt forskes der $i$ begge genrer. Stambøgerne er behandlet i Stammbücher als kulturhistorische Quellen, hrsg. von Jörg-Ulrich Fechner. München 1981 (= Wolfenbütteler Forschungen Bd. 11), mens orientering om et igangværende projekt til registrering af samtlige bevarede stambøger findes i Internationales Archiv für Sozialgeschichte der deutschen Literatur x, 1985, s. 167-69. Ligprædikenernes rige stof og dets kildeværdi er emnet for forelфbig tre bind med titlen Leichenpredigten als Quelle historischer Wissenschaften, hrsg. von Rudolf Lenz. I-III. Köln 1975-83.

I særlig gunstige tilfælde er det muligt at følge udenlandsrejser gennem dagbøger og breve, kilder der kan være givende med hensyn til de rejsendes hverdag, studier og oplevelser. Som eksempler på oplysende udgivelser inden for den sidste snes år skal af dagbøger anf $\phi$ res Peder Hegelunds Almanakoptegnelser 1565-1613. Udg. ved Bue Kaae. I-II. Ribe 1976. Den senere biskop i Ribe stu- 


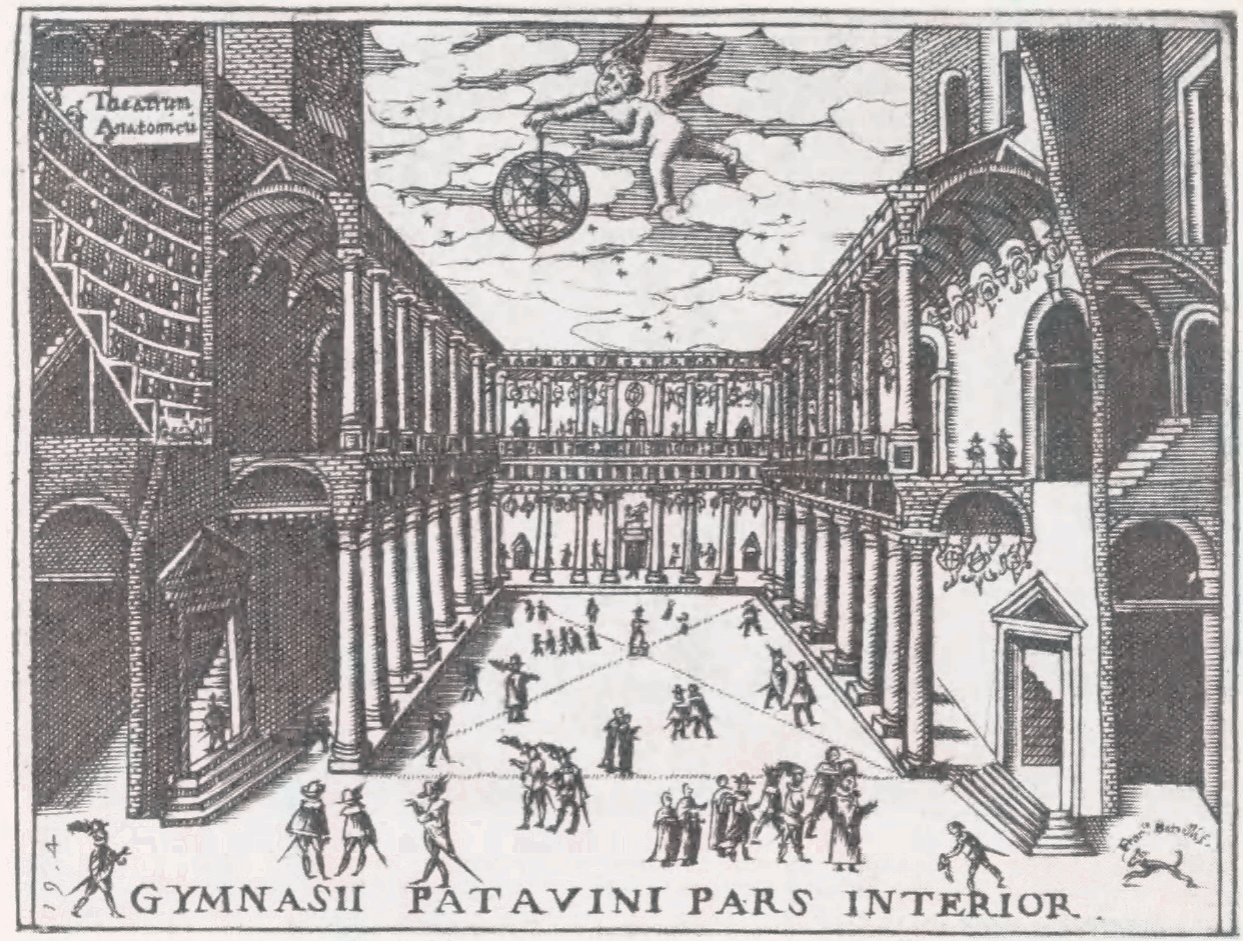

Universitetet $i$ Padova blev besøgt af mange danske og var iscer berømt som studiested for medicinere. På dette kobberstik fra begyndelsen af 1600-tallet ses $i$ tvcersnit $\phi v e r s t$ til venstre anatomisalen (indrettet 1594 og endnu bevaret). Om en dansk lege, der slog sig ned i byen på Christian IV's tid og blev en god støtte for besøgende landsmend, se Egill Snorrason: Johan Rhode $i$ det 17. àrhundredes Padua, 1964.

derede i Leipzig og Wittenberg 1565-68 og fortæller bl.a. om forelæsninger, han fulgte, og landsmænd han var sammen med. Fra da han derefter slog sig ned $i$ Ribe, noterede han lфbende i sin kalender, når ham bekendte udenlandsstuderende passerede byen på vej ud eller tilbage. Heraf fremstår noget i retning af et ripensisk ud- og hjemrejseregister. En regulær dagbog ført af en ung adelsmand på farten, senere kendt som fremtrædende rigsråd, foreligger trykt med Christen Skeels resedagbok 1619-27. Utg. av Lennart Tomner. Malmö 1962. Christen Skeel refererer upersonligt, men uhyre samvittighedsfuldt, hvad han så på sin store tur gennem Nederlandene, England, Frankrig og Italien. Helt i særklasse som lærdoms- og videnskabshistorisk kilde er Ole Borchs studiedagb $\varnothing-$ ger fra Nederlandene, England og Frankrig 1660-65. Borch var lige blevet professor, da han fik bevilget støtte til studier i udlandet, så det var en kompetent studerende, der 1660 gav sig til at 


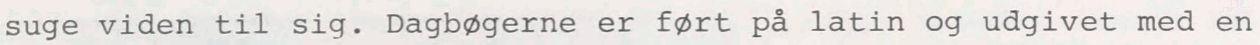
indledning på engelsk som Olai Borrichii Itinerarium 1660-65. Ed. by H.D. Schepelern. I-IV. Kbh./London 1983.

Det er næppe forkert at betegne ole Worms Breve 1607-1654. Oversat af H.D. Schepelern. I-III. Kbh. 1965-68 som en af de mest righoldige brevsamlinger fra 1600-tallet med en dansker som centrum. Brevene rummer ikke meget om Worms egen udenlandsrejse i årene omkring 1610 - den har H.D. Schepelern til gengæld fulgt ved hjælp af hans to stambøger $i$ en afhandling $i$ Kulturminder, Ny række IV, 1961, s. 19-54 - men Worm havde et stort interessefelt, og han $n \phi d$ som professor og videnskabsmand stor tillid. Derfor modtog han gennem mere end en menneskealder talrige breve fra elever, slægtninge og bekendte på rejse $i$ udlandet, hvori de rapporterede om deres studier eller forelagde ham deres problemer. Her fortælles om biblioteksbes $\phi g$, overværelse af dissektioner, mфder med lærde mænd og meget andet, som kan findes via udgavens fortræffelige registre. Mere beskedne af indhold er nogle breve hjem fra Søren Andersen Vedel, da han opholdt sig som student i Tyskland 1606. De er udgivet og kommenteret i Familieliv på "Li jebjerget" $i$ Ribe omkring 1600 belyst gennem breve. Ved Bue Kaae, Esbjerg 1983, s. 17-38. En rørende forsikring til de bekymrede forældre om, at han passer godt på i det fremmede, citeres fra s. 22: "Mit guld har jeg indsyet nede $i$ mine inderste bukser imellem stopningen, saa at ingen kan føle det. Jeg tænker det er dér vel forvaret med Guds hjælp" !

Andre sider af rejselivet belyses kulturhistorisk af nogle rejseråd meddelt af den berømte mediciner Thomas Bartholin. Henvendt til sine lægestuderende sфnner tilråder han bl.a. hygiejniske foranstaltninger som at filtrere urent drikkevand og anbefaler dem at ops $\phi$ ge nærmere angivne seværdigheder på deres vej. Rådene bygger på hans egne erfaringer fra Frankrig og navnlig Italien $i$ begyndelsen af 1640'erne. De er oversat fra latin til engelsk i Thomas Bartholin: On the burning of his library and on medical travel, translated by Charles D. O'Malley, Lawrence 1961, s. 43-101.

Over 3.000 danskere har if $\varnothing$ lge Vello Helks optælling foretaget én eller flere studierejser i udlandet mellem 1536 og 1660 . Heraf var 20-25\% adelige. I betragtning af at de unge adelsjunke$i$ hvert fald $i$ de første rejseår har rejst under opsyn af en præceptor, må der jævnligt være blevet truffet aftaler mellem 
Som turister oplevede nordboerne det farverige $l i v$ i syden, katolske ceremonier og processioner, folkelige skuespil og fester. I en italiensk rejsefører, Nuovo Itinerario d'ItaZia di Andrea Scoto, Vicenza 1638-39, indgår en billedserie med titien 'Il carnevale ItaIiano Mascherato', hvorfra disse figurer er hentet.

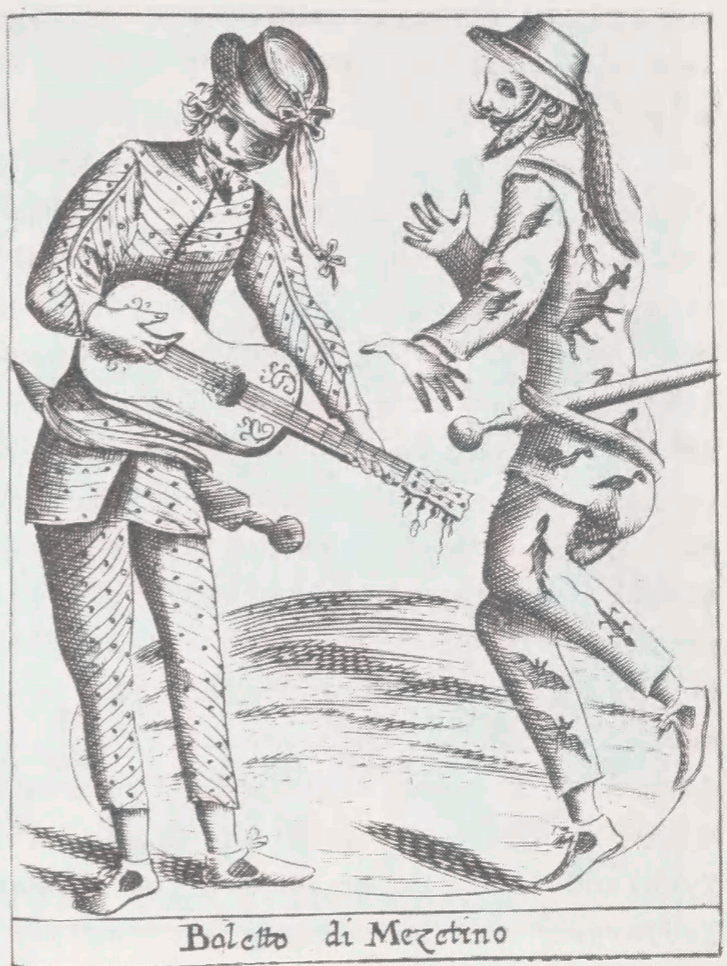

forældre og præceptor om dennes kompetence og planen for rejsen, men herom ved vi forbavsende lidt. F $\phi r 1660$ synes yderst få kilder af typen rejsefuldmagter og -instrukser bevaret, hфjst en 5-6 stykker. En instruks udstedt 1598 af Peder Brahe for Jens Mule som præceptor for sфnnen Axel er trykt i Ny Kirkehistoriske Samlinger, V, 1869-71, s. 253-55, mens en instruks i seks punkter fra 1643 angående Ove Thotts udenlandsrejse blot er kort refereret i Historisk Tidsskrift, 5. rk. I, 1879, s. 11. Mellem disse to aktstykker ligger altså 45 år. Indimellem kan nu føjes en rejsefuldmagt udstedt 1613 af Jakob Ulfeldt. Den findes i afskrift i Ny kgl. Samling $1977^{b} 4^{\circ}$ og aftrykkes her.

\section{JAKOB ULFELDT OG HANS SØNNER}

Jakob Ulfeldt (1587-1639) levede om nogen op til idealet af den "sande" hфjt uddannede adelsmand. Ca. 1583-96 studerede han ved udenlandske universiteter og begav sig ud på lange rejser, som 


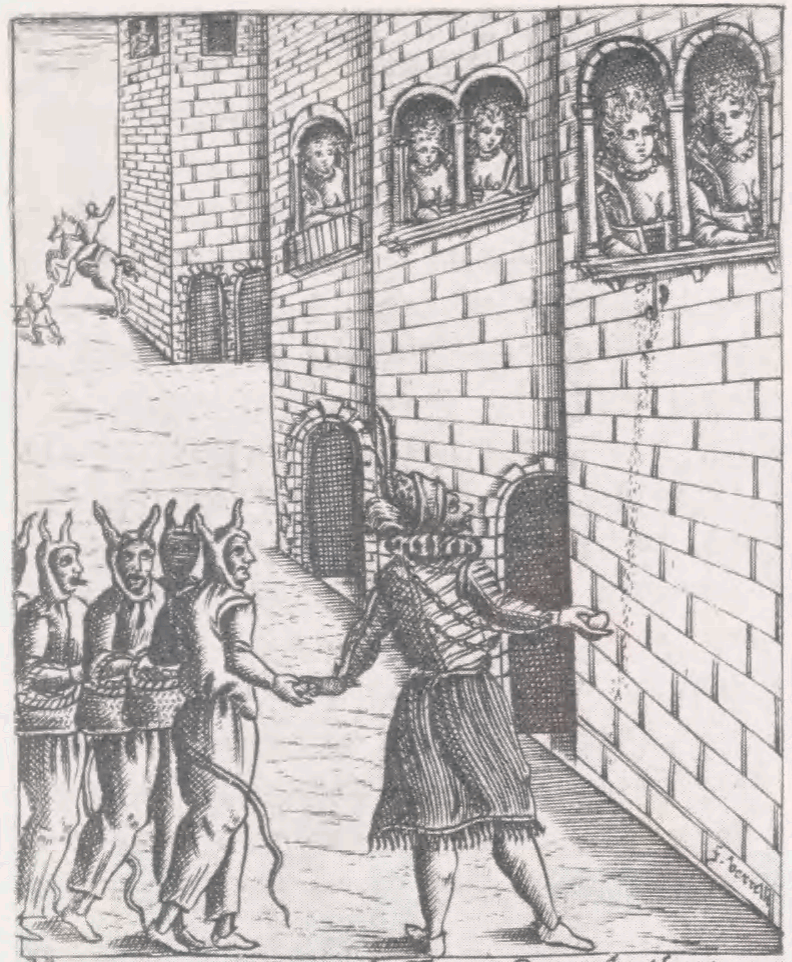

Scene fra 'Il carnevale ItaZiano Mascherato'.

Mascare usate in Venetia the Tirano Oni odoriferi -

foruden det meste af Europa inkluderede Egypten og Konstantinopel. Enkelte af de mange stationer på hans færden kan følges via no-

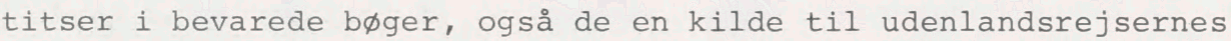
historie. Ligesom flere andre bogkфbere har han foruden sit navn skrevet år og sted i bøger, han erhvervede undervejs. Således fremgår det at han bes $\varnothing$ gte Rom 1588, Madrid, Salamanca og Sevilla 1595, Cordoba 1596. Anskaffelserne er i sig selv vidnesbyrd om hans boglige interesser, og af en liste over bøger, han ca. 1600 $\varnothing$ nskede opstillet til daglig rådighed, fornemmes en bred horisont ligesom det ses, at han var kyndig i adskillige sprog, i hvert fald latin, tysk, fransk, italiensk og spansk.

Jakob Ulfeldt var fra 1607 rigsråd, fra 1609 tillige rigskansler, og med sine gode kundskaber blev han ikke overraskende flittigt anvendt af Christian IV til udf $\phi$ relse af diplomatiske hverv $i$ udlandet. Af og til blev der dog også tid til lidt privatliv på hans fynske gårde. Mellem 1600 og 1621 fik han 17 børn: 11 s $\varnothing$ nner og 6 d $\phi$ tre. Blandt s $\phi$ nnerne var Laurits, hvis bibliotek blev en af grundpillerne i det af Frederik III stiftede kongelige 
bibliotek - sandsynligvis forklaringen på at Det kongelige Bibliotek har bøger, der stammer fra faderen - og der var Corfits, som ægtede kongens dàtter og kom højt på strå, men som også oplevede det dybe fald og døde som erklæret landsforræder.

Det er nu interessant at se, hvordan fader Ulfeldt organiserede sine mange sфnners skolegang og uddannelse. Han delte dem simpelthen i hold. Det første bestånde af Knud, Jakob og Frants, født 1600-1601, blev 1613 med Ole Jakobsen som præceptor sendt til pædagogiet i Herborn. Næste hold, der bestod af Peder, Laurits og Corfits, født 1604-06, blev efter nogle år på Herlufsholm sendt til udlandet 1617 eller 1618. Dette hold 2 sluttede sig nu til hold 1. Alle seks troppede sammen med Ole Jakobsen op og lod sig immatrikulere ved universitetet $i$ Genève 1618, og sammen rejste hele flokken nogle måneder senere derfra videre til orlèans. I de følgende år skete der det, at det $i$ forbindelse med oprettelsen af akademiet i Sor $\varnothing$ blev forbudt adelen at sende dens børn udenlands i tidlig alder, dvs. f $\phi$ rend de evt. havde gået på Sor $\varnothing$. Det tredje hold, Flemming, Ebbe og Eiler, født 1607-13, kom derfor 1623 til skolen og akademiet i Sor $\varnothing$, som de så iøvrigt forlod til forskellig tid.

Navnlig uddannelsen af de to første hold må have kostet Jakob Ulfeldt store summer. Bortset fra Peder, der d $\varnothing$ de 1621, synes de at have opholdt sig udenlands på faderens bekostning til slutår engang mellem 1625 og 1630, altså gennemsnitligt i henved tolv år. På denne baggrund kan det ikke undre, at Charles ogier fandt Knud, Laurits og Corfits sprogkyndige og rige på kundskaber, da han 1634 traf dem i Danmark. Det skulle bare have manglet!

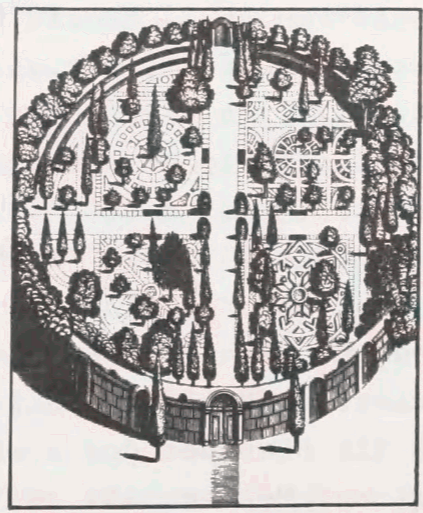

Den botaniske have $i$ gymnasiet $i$ Padova. - J.P. Tomasini "Gymnasium Patavinum". 1654. 
Den fuldmagt, Ole Jakobsen blev udstyret med i påsken 1613, har karakter af en kontrakt, hvoraf hver af parterne udtrykkeligt skulle have sin genpart. Da afskriften gengiver Jakob Ulfeldts underskrift, er der tale om Ole Jakobsens eksemplar. Kontrakten gjaldt for fem år og sikrede Jakobsen et ikke pristalsreguleret honorar på 100 daler årligt plus fri kost, bolig og rejsebefordring. Bemærkelsesværdig er bestemmelsen om, at han skulle aflastes i sit arbejde ved at holde tjenermedhjælp. "En smuk, skikkelig og lærd person" skulle medhjælperen være - med andre ord en pæn og artig student. Med denne kom selskabet op på fem personer.

Da førsteholdsdrengene i 1613 kun var 12-13 år gamle, er det næppe påfaldende, at Ulfeldt undlod at specificere et undervisningsprogram, der nфdvendigvis måtte blive ret elementært. Dagli-

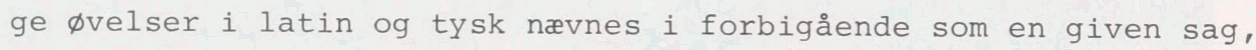
men først og fremmest lå det ham på sinde at få tilkendegivet, at hans børn skulle opdrages $i$ tugt, ære og gudsfrygt. Alt i alt udgør fuldmagten en tillidserklæring til præceptoren, som må siges at have fået meget frie hænder.

ole Jakobsen (1588-1638) havde i kraft af sin herkomst en vis social status, idet han var $s \phi n$ af den afdфde biskop over Fyn Jakob Madsen. Til hans fordel har selvsagt også talt, at han var kendt med forholdene i rejsemålet Tyskland, hvor han havde studeret ved flere universiteter 1608-12. Han blev 1626 dr.med. i Padova og slog sig ca. 1630 ned som læge i Odense. Hvor længe han fortsatte som lфnnet praceptor er uvist, men forbindelse til Ulfeldtsønnerne har han opretholdt til i det mindste 1626. I et eksemplar af Quintus Curtius' skildring af Alexander den Stores historie - trykt i Lyon 1555 og nu med signaturen 171-122 $8^{\circ}$ - har Lauritz skrevet, at bogen blev foræret ham som et hengivenhedstegn af dr. Jakobsen: "Mons ${ }^{r}$ le $D[$ octeur] Jacobæus m'a faict presant de ce liure en tesmoignage de sa très fidelle affection. L Ullfd".

I det følgende fuldmagten $i$ afskriftens ordlyd. Nogle ord og vendinger, som ikke umiddelbart forstås, står forklaret til sidst.

Nceste sider: Jakob Ulfeldt bcenket ved bordet med hustru, børn og hund. De 11 sфnner sidder efter alder til højre for husherren, de 6 døtre tilsvarende på husfmens side. Ligesom baggrunden udgøres af en fantasi-kulisse er familiescenen konstmieret. På grund af sønnernes langvarige udenlandsophold har Jakob Ulfeldt næepe set alle sine børm samlet, og ikke mindst: da den yngste $i 1621$ så lyset, var både en celdre søster og bror døde! - Kobberstik $i$ folioformat efter maleri på Frederiksborg. 


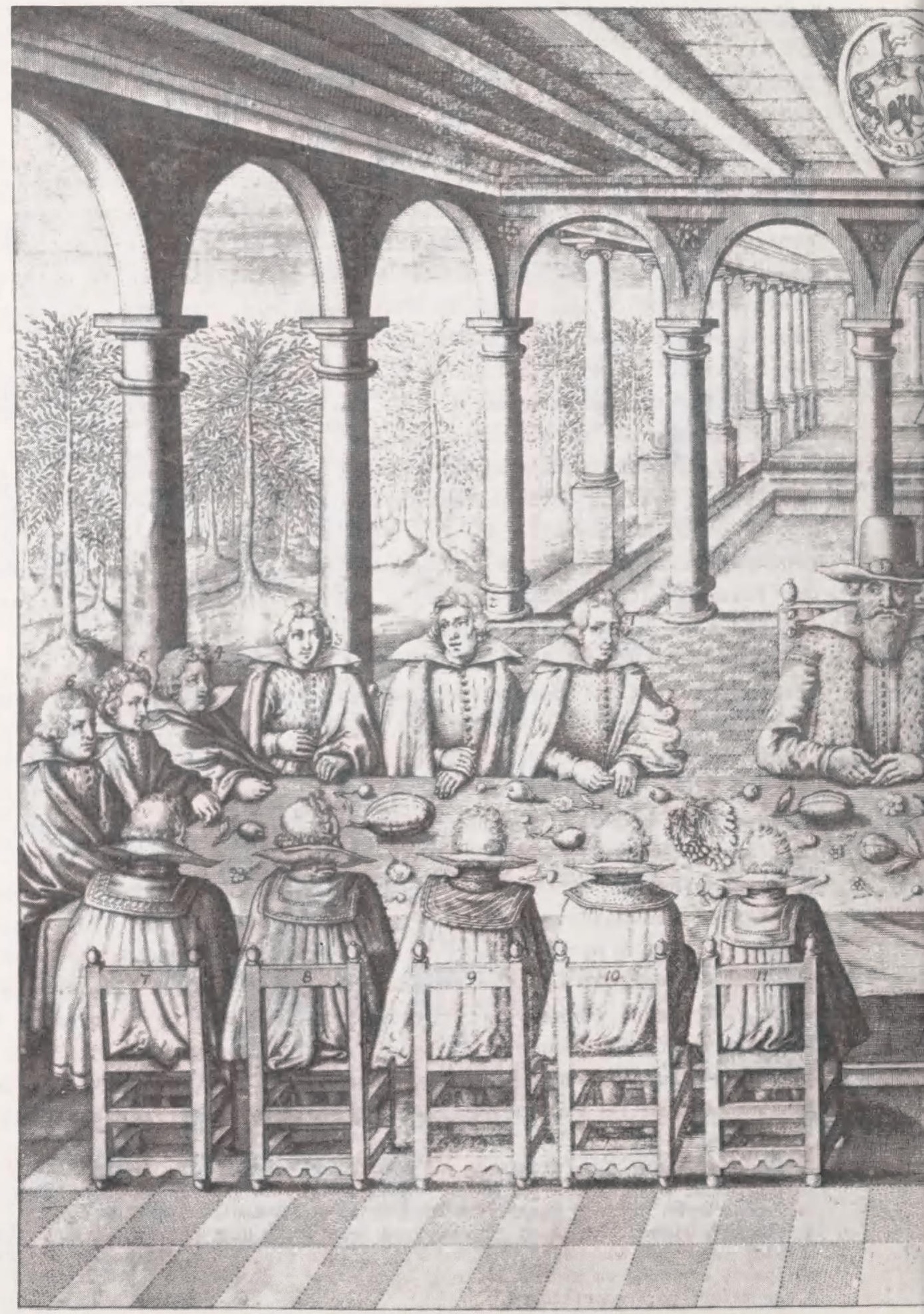




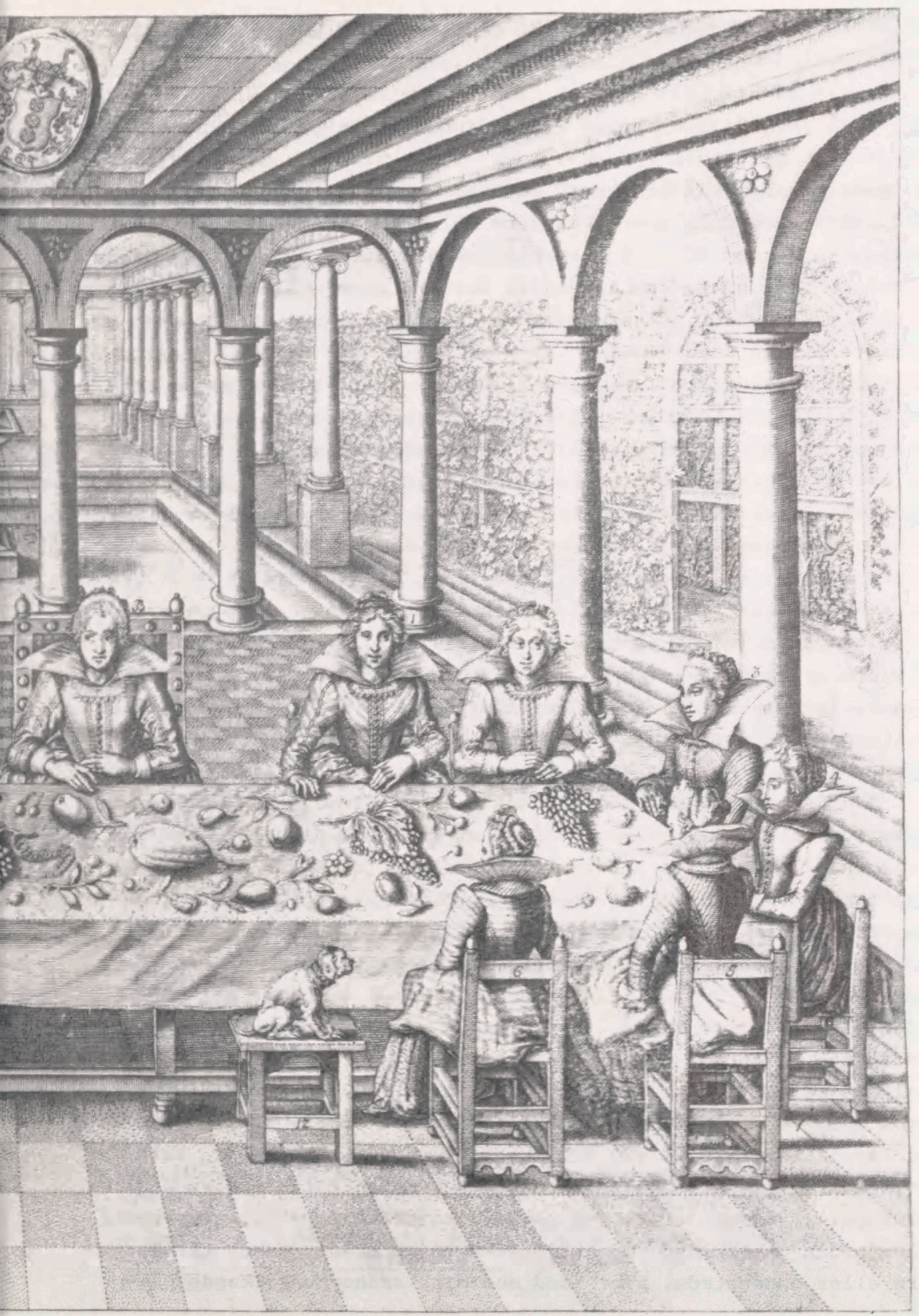




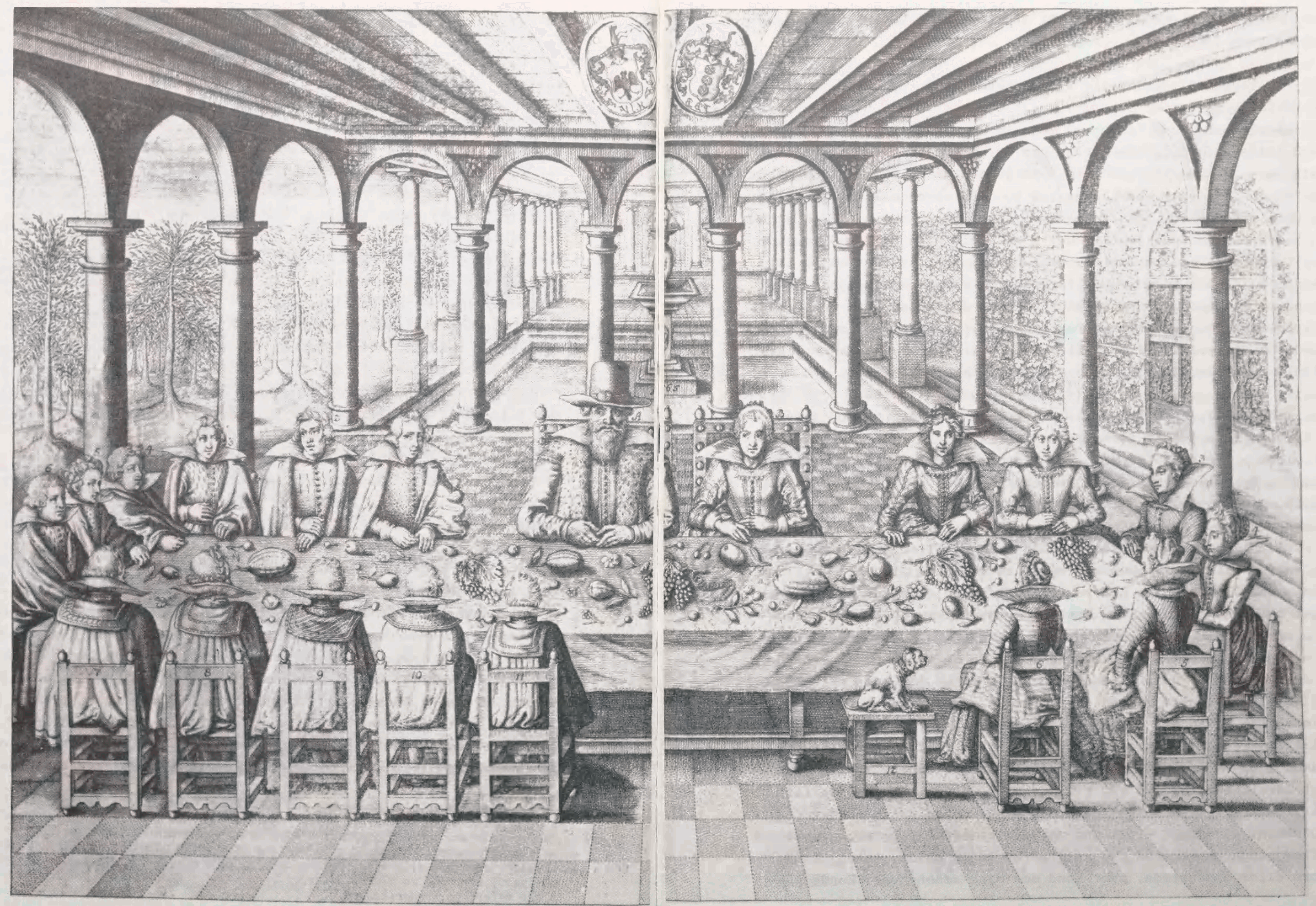


COPIE AFF DEN FULDMAGT, SOM WELB: JACOB WLDFELD GAV D, OLUFF JACOBSEN OVER SINE BØRN

Effter at jeg udi den Hellig Trefoldigheds nafn nu udsender udi Germaniam mine Sфnner Canutum, Jacob og Frantz, der med Guds hielp og naade at lære udi lærdom og lefnet, det Gud Allmægtigste kan være til ære og lof, deres Forældre til glæde, dem selffver til gafn og gode, den Allmægtigste Naadige Gud gifve der til sin naade og velsignelse etc., da hafver jeg forhandlet og tilbetroet Erlig og Welllærde Person, OZuff Jacobsøn at følge dennem udaf landet og at hafve dennem fuldkommelig udi i sin befalning som en Preceptor, med fuldkommen og absolut fuldmagt dennem at forestaae baade udi lærdom og lefnet, som jeg self personlig var tilstæde. Skal [han] og nu og altiid her effter hafve udi sin forvaring alle hvis penge ieg til deres underholdning forordner og forsender, og dennem anvende og udgive efftersom leiligheden udkræver, saa børnene bliver altiid reenligen og vel holdet baade med kost og klæder, ratione cetatis et locorum, cum frugali liberalitate et liberali frugalitate, saa at alle ting kand gaae skickeligen og vel til, og hafver oluff Jacobsøn lofvet og tilsagt mig herpaa sin troe tieniste, og at vilde blive hos mine børn uden lands (hvor Gud vil de effterhaanden forreiser) udi fulde fem samfelde aar, og icke drage eller begive sig fra dennem udi nogen maade, men stedse saa længe blifve hos dennem og følge dennem.

Saa hafver ieg for saadan hans umag og fliid lofvet og hermed lofver og tilsiger annuum salarium, Et hundrede Rixdaler, hvilcke hannem aarligen skulle blifve til gode reede erlagde, og derhos hans frie underholding til kost, woning, reiser og saadant, ligesom børnene det hafver. Dersom ieg bliver tilsinds at lade affor-

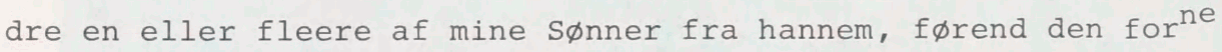
tid er forlфben, da skal derfor aldelis intet afkortes udi hans salario, desligeste om ieg vil forsende af mine sфnner en eller fleere til de andre, som hand nu strax annammer udi disciplin, da skal han dennem annamme og instituere lige ved de andre for det samme salario, og effterat det er nu foraffskeedet, at hand for det første skal begive sig til Herborn, og der paa to aars tiid stille forblive, saa skal hand dog baade nu og altiid hafve den fuldmagt, at dersom - det Gud naadeligen affvende - nogen contagie eller anden usickerhed med krig eller anden maade, enten til Herborn eller andensteds, hvor hand med mine sфnner var, kunde paa- 
komme, at hand maae begifve sig strax derfra paa andre beqvemmelige stæder, som sicker ere, hvor børnene kunde have god leylighed for deres lærdom og underviisning, og skal hand altiid det snareste mueligste mig derom tilskrive og lade mig viide, hvor hand med børnene migrerer.

Og paa det børnene kunde have dis bedre deres exercitia quotidiana, saa vel in Lingva Latina som Germanica, da skal hand altiid holde for dennem Zoco famuli en smuck, skickelig og lærd Person, hvilcken hand maa besolde effter saadan en persons qualitet, og icke ansee en ringe ting, paa hvis børnene kunde hafve gafn og forfremmelse af.

De ratione institutionis giфres intet fornфden at specificere, men [jeg] forlader mig til hans gode troe og discretion, alleniste for alle ting at mine børn ideligen og dagligen holdes til Guds frygt, $\varnothing$ fves dagligen udi bønner og psalmer, opdrages udi et ærligt, tugtigt lefnet, holdes fra alt ont selskab, og hafver omgang med de gode, udaf hvilcke de kunde see og lære det, som got er.

Den Evige, Allmægtige, Naadige Gud, som hafver skabt dennem og igienlфst dennem til sin ære, hand ledsage dennem med sine hellige Engle og bevare dennem, hand regiere dennem med sin hellig Aand paa sine hellige veie og lære dennem all sandheds og retfærdigheds veie og vidnesbyrd, og gifve dennem lycke, naade og velsignelse, at de maa blifve hellige lemmer udi hanss hellige Meenighed, som hannem kunde lofve og priise, at vi saa tilsammen maa lofve, ære og priise hans hellige nafn herpaa jorden, og siden i all ævighed, Amen.

Til ydermeere vidnesbiurd og ihukommelse ere tvende skriffter ennsliudendes os imellem giort, som vi hafve med egne hænder underskrevet, saa hver haver en part derudaff. Datum Nyborg slott Paaske Hellige dage [dvs 4. april] Anno 1613.

Jacob Wlffeldt

præceptor lærer og vejleder ratione atatis etc. i forhold til alder og sted, hverken for $\not$ dselt eller for påholdende annuum salarium årsløn for førnævnte instituere oplære foraffskeedet aftalt contagie epidemi migrerer rejser hen exercitia etc. daglige undervisnings $\phi$ velser loco

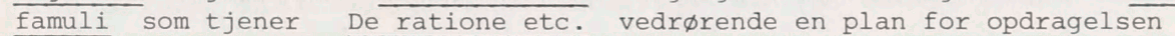
discretion konduite. 
